\section{SOME PAPERS ON INVERTEBRATES}

COMMENCING with entomology, mention may be made of a paper on new and little-known North American Tipulidæ, by Mr. C. W. Johnson, published in vol. xxxiv., pp. 115-33, of the Proceedings of the Boston Natural History Society. In addition to the description of a number of new species, the paper contains the diagnosis of the new genus Aeshnasoma, proposed for a large tipulid with antennæ of the type of those of Longurio, but with a wing-venation differing from both that genus and Tipula.

To the March number of Spolia Zeylanica Mr. T. B. Fletcher communicates the first part of a monograph of the plume-moths of Ceylon, dealing in this instance with the members of the family Pterophoridæ. There are, it will be remembered, two families of plume-moths, the one already mentioned and the Orneodidæ, or 24-plumed group. Both are regarded by the author as very ancient types, but there appears to be little or no near relationship between the two groups, so that their mutual resemblance may probably be attributed to convergence. Although nothing definite is known in regard to the advantage gained by the splitting of the wings in these moths, the author suggests that when pace is not essential, a light framework of wing supplemented by cilia will be superior to the ordinary lepidopterous wing, in that it gives an equal measure of support with less expenditure of muscular force. In the same issue $\mathrm{Mr}$. P. Cameron describes certain new Ichneumonidæe and Braconidx reared by Mr. Fletcher from Ceylonese plume-moths.

Part $v$. of the second volume of Records of the Indian Museum is devoted to the revision, by Mr. E. Brunetti, of two groups of Oriental insects, namely, the flies of the families Leptidæ and Bombyliidæ; the latter paper containing a list of the known Oriental species, of which some are described for the first time.

To the Proceedings of the South London Entomological and Natural History Society for 1908-9 Mr. H. S. Fremlin contributes a paper on the results of experiments to show the effect of physical and chemical agencies on butterfly pupæ. The species forming the subject of the experiments were Vanessa urticae and Abraxas grossulariata, the total number of specimens treated being just over two thousand. Water and high temperature were the agents for the influence of physical conditions, while the chemical agencies employed were nitric and hydrochloric acids, chloride of lime, sulphur, hydrogen sulphide, and carbon disulphide. In the case of $V$. urticae, the death-rate was excessive when the pupæ were exposed to continuous high temperature, hydrogen sulphide, and carbon disulphide. The pupa of $A$. grossulariata were in great measure destroyed in the water-laden atmosphere, and in the continuous high temperature failed to develop; hydrogen sulphide, on the other hand, was less harmful than in the case of the other species, although it crippled such adults as developed. Chlorine had a marked effect on the red colour of urticae, but showed little result in the case of grossulariata.

'To the June number of the Entomologists' Monthly Magazine Mr. R. S. Bagnall contributes an account of four species of Thysanoptera new to the British fauna, among which Megathrips nobilis is also new to science. That species, the largest European representative of the group, was first obtained by Dr. D. Sharp in Wicken Fen during 1896 .

Leaving insects for arachnids, we find in the April issue of the Proceedings of the Philadelphia Academy Mr. N Banks cataloguing a collection of spiders from Costa Rica, with descriptions of new species. The new forms are about seventy in number, in addition to which there are about a score of species not mentioned in "Biologia Centrali-Americana." Of the web-making species, a considerable number are common to the United States, but of the other groups few kinds range so far north.

To vol. xxxviii., part iv., of the Travaux Soc. Inip. Nat. St. Pétersbourg, Mr. E. K. Suworow contributes an elaborate account of the anatomy of Ixodes reduvius. a tick exhibiting sexual dimorphism in a strongly marked degree. The much smaller males are, for instance, distinguished from the females by a peculiar system of divisions in the external envelope of the body, while there NO. 2070, VOL. $8 \mathrm{I}]$ are also histological differences in the hypodermis of the males as compared with that of the females, as well as distinctive features in the mouth-organs.

Three papers published by the U.S. National Museumtwo in the Proceedings and one in the Bulletins-are devoted to crinoids. In the first of these (Proceedings, vol. xxxvi., pp. 39I-4Io) Mr. A. H. Clark describes a second collection of these organisms obtained by the S.S. Albatross, of which fifteen species, together with four left over from the first collection, are regarded as new, and duly named, one of these forming the type of a new genus. Eudoxocrinus alternicirrus, hitherto known only by Challenger specimens, has been re-discovered, and its habitat definitely determined, but several other Challenger forms have not been met with.

In the second of these papers (Bulletin No. 64) Miss Elvira Wood, of Columbia University, gives a critical summary of Dr. Gerard Troost's unpublished monograph of the fossil crinoids of Tennessee. Dr. Troost, who was born in Holland in 1776 , settled in Philadelphia in 1810 where he became one of the founders, and the first president, of the Academy of Sciences. In 1827 he removed to Tennessee, where he became professor of geology and mineralogy in Nashville University, holding that chair until his death in 1850 . Only about a month before his death the manuscript of the monograph of Tennessee crinoids was sent to the Smithsonian Institution for publication. After passing through various hands for five years, this manuscript came into the possession of Prof. Hall, in whose custody it remained for upwards of forty years. The long period which has elapsed since it was written rendered re-writing practically imperative, but certain portions have been printed direct from the original MS. Many of the original illustrations have been replaced by photographs or new drawings.

In the third paper of this series (Proceedings, vol. xxxvi., pp. I79-9o) Mr. Springer describes, under the name of Isocrinus knighti, a new crinoid from the Jurassic of Wyoming.

The molluscs collected on the north side of the Bay of Biscay by the Huxley in the summer of 1906 form the subject of an article by Mr. A. Reynell in vol. viii., No. 4, of the Journal of the Marine Biological Association. Out of the seventy-five species collected, sixty-two have been recorded from the British area.

In No. 1678 of the Proceedings of the U.S. National Museum (pp. 43I-4) Miss H. Richardson describes and figures a specimen of the curious spiny woodlouse (Acanthoniscus spiniger) of Jamaica. Although this isopod is stated to be common in its native island, the type-specimen in the British Museum and the one described by Miss Richardson are believed to be the only examples in collections.

\section{THE RESEARCH DEFENCE SOCIETY.}

$T H E$ speeches at the annual general meeting on June 25 of the Research Defence Society illustrated the wide and manifold interests of its work. It is, indeed, a national society for telling the truth about a matter of national importance. It defends the good name, the honour, of science against reckless and unscrupulous opponents, and we are not surprised at the welcome that it recoived. The list of its 2500 members includes a very powerful and thoroughly representative collection of great names. The society has already formed a dozen branch societies, has given many lectures, and has distributed much wholesome and honest literature; it has also published a volume of essays, written with authority, and pleasantly free from all controversy. Thus it has begun well; and the report of its committee is justly satisfied with the work of the past year. We note here two of the points made by speakers at the annual meeting.

Sir James Dewar emphasised this fart, that Germany is far ahead of us in the equipment of great laboratories for research in the "borderland between physiology and chemistry." Money is spent lavishly over the investigation of organic chemical bodies, the discovery and the preparation of new organic drugs. The services of a hundred expert and highly qualified men of science are at the command of a single firm. They receive large salarics, 
and are free, to follow the bent of this or that special study. In the long run, their united work is immensely profitable. Here is commercial rivalry, and more; here is a better understanding of the right conditions of " applied science."

Lord Cromer, president of the society, took as a signal instance of the necessity for experiments on animals the recent discovery of a serum treatment in cases of epidemic cerebro-spinal meningitis, that ghastly disease which goes by the foolish name of "spotted fever." It is an acute septic inflammation of the membranes of the brain and the spinal cord. By experiments on animals it was proved to be due to special germs of the order of diplococci. Flexner and Jobling, working at the Rockefeller Institute, discovered a way of preparing, from immunised horses, a serum containing a direct antidote, and this serum was first used in the spring of 1907 . Before that time there was no special treatment of the discase, and the mortality ranged from 68.4 per cent. to 80.5 per cent. The children -it was mostly children-suffered terribly, and died in a few days; and of those who survived many were left, from the intensity of the inflammation, imbecile, paralysed, or blind. $\mathrm{By}$ the use of the serum the mortality has been reduced to 36.7 per cent. In Belfast, of 275 cases treated before the use of the serum, $72 \cdot 3$ per cent. died, and of ninety-eight cases treated with the serum $29 \cdot 6$ per cent. died.

The Research Defence Society exists to keep the public informed of such facts as these, and we hope that it will have a long record of such victories over disease.

\section{IS THE ASSOCIATION OF ANTS WITH} TREES A TRUE SYMBIOSIS?

THE fact has long been known that some species of ants occur in constant association with certain kinds of trees. Thus members of the dolichoderid genus Azteca are often found inhabiting the interior of the stems of Cecropia peltata, and among the Pseudomyrmini $P$. bicolor forms its nests within the spines of the "bull's-horn" acacia. The view has been held by many naturalists, amongst others by Fritz Müller and Bates, that in these cases the benefit is mutual, the tree affording both shelter and sustenance to its occupants, and receiving in return protection from the attacks of the formidable leaf-cutting ants of the genus Atta and of other enemies. Doubts on this point have been expressed by several authorities, among them by Dr. David Sharp, in whose opinion " there is reason to suppose that a critical view of the subject will not support the idea of the association being of supreme importance to the trees."

A careful investigation of the relations subsisting between the arboreal species of Azteca and Pseudomyrma and the trees which they inhabit has lately been conducted in Paraguay by Karl Fiebrig, who has published his results, illustrated by numerous photographic reproductions, in the current volume of the Biologisches Centralblatt. ${ }^{1}$ His conclusions mav be summarised as follows :-

Azteca not only makes use of internodal cavities already existing in the stem of Cecropia peltata, but excavates fresh spaces or enlarges existing ones at the expense of living tissues of the tree. Fritz Müller described certain pits in the stem of Cecropia where the wall is much thinner. These spots, he says, are selected by the female ant for the purpose of gaining access to the interior of the stem. But, according to Fiebrig, the ants effect their entrance into new internodal spaces by perforating the partitions in the sten before they have gnawed through the thin bottoms of the pits; moreover, openings to the exterior are often made irrespective of the situation of the pits, and when the latter are perforated the boring is, in certain cases, effected from within, and not from without. Neither the internodal spaces nor the pits can therefore reasonably be considered as myrmecophilous adaptations. Again, the alleged protection against leaf-cutting ants must often be superfluous, since the Cecropia, with its

1 “'Cecropia nel'ata und jhr Verhälin's zu Aztora Alfari, zu Atta sexdens und anderen Insekten. Ein kritischer Reitrag zur Ameisenpflanzen-Hypothese." By Karl Fiebrig (San Bernardino, Paraguay).

NO. 2070 , VOL. 81] inmates, is apt to be found in marshy situations where these encmies cannot reach it. Most of the trees in Paraguay are subject to the attacks of the leaf-cutting Atta, but, nevertheless, though unprotected by the presence of Azteca, they continue to maintain their existence, even if belonging to introduced, and not native, species. Cecropia itself is not tenanted by ants until it is some years old. The presence of colonies of Azteca does not prevent Cecropia from receiving much damage from the attacks of other insect enemies, and Fiebrig is of opinion that the constant loss suffered by the tree from the depredations of Azteca itself involves a more serious drain upon its vitality than the occasional raids of the leafcutters. Finally, the occupation of Cecropia by these ants not only fails to afford protection against enemies other than the leaf-cutters, but even encourages the assaults of such formidable foes as woodpeckers and internally feeding lepidopterous larvæ.

With regard to the association between Acacia cavena and Pseudomyrma fiebrigi, the author points out that this tree, in common with other species of Acacia, is protected against the ground-haunting Atta by the fact that it grows only in situations which are constantly liable to inundation. The thorns in which the ants take up their abode have frequently been already hollowed out and furnished with apertures of access by lepidopterous larvæ; moreover, the spaces tenanted by the ants are not confined to the thorns, but extend also to the stem. In neither situation do they occur naturally, but in both they are excavated, as in Cecropia, whether by ants or caterpillars, at the expense of the living tissues of the tree.

On these grounds Fiebrig concludes that, at any rate so far as the species observed by him are concerned, the benefits of the association between trees and ants are not mutual, but are enioyed by the ants alone. There is no doubt that the reasons for his view adduced by Fiebrig are of great weight. At the same time, it cannot be said that these observations are sufficient of themselves to disprove altogether the existence of ant-plant symbiosis.

F. A. D.

\section{UNIVERSITY AND EDUCATIONAL INTELLIGENCE.}

OxFord.-The following is the text of the speech delivered by Prof. Love in presenting Dr. G. E. Hale for the degree of D.Sc., honoris causa, at the Encænia on June 24 :-

Inter Astronomos qui ea quæ in xthere solem circumfuso geruntur investigant nemini cedit. Georgius Ellery Hale. Qui vír duodeviginti abhinc annos primus omnium fabricatus est instrumentum illud, ad lucis e solis puncto quovis emissa naturam cognoscendam aptissimum, quo hodie utuntur omnes fere solis observatores. Hoc subsidio fretus potuit flammas illas excurrentes, quæ solis defectu plerumque cernuntur, sole pleno quasi in pictura exprimere: mox plagas lucidissimo candore fulgentes, quas faculas vocant, eodem modo repræsentare. Idem nuper docuit procellis hunc æthera vexantibus tenuissimas materix particulas quasi turbine quodam agitatas vim magneticam miro modo gignere: quæ omnia nemo demonstrare potuit nisi excogitandi peritissimus, in observando patientissimus, in causis cognoscendis sagacissimus. Neque ei satis erat Natura arcana reserare, sed Observatoria duo in orbe terræ maxima fere et instructissima condidit atque ornavit: idem Ephemeridem, in qua recentissima de siderum natura ubique reperta pervulgantur, conscribendam curavit. Sodalicium denique maximum instituit quo omnes omnibus ex terris huius militiæ cælestis contubernales congregarentur.

ST. Andrews.-Dr. William Nicoll, who has for some years carried out important researches on the parasites of birds, fishes, and other forms at the Gatty Marine Laboratory, has just been elected to the Ernest Hart memorial scholarship.

Dr. J. C. Irvine, lecturer on organic chemistry in the University, has been appointed by the University court to the chair of chemistry in St. Andrcws, vacant by the resignation of Prof. Purdie. 